\title{
Natural Disasters and Economic Growth: a Synthesis of Empirical Evidence
}

\author{
Desastres naturales y crecimiento económico: \\ una síntesis de la evidencia empírica
}

Fernando Antonio Ignacio González ${ }^{1}$

Fecha de recepción: 12 de marzo de 2021

Fecha de aceptación: 15 de abril de 2021

1 - Nacionalidad: Mexicana. Grado: Maestría en Economía. Adscripción: Instituto de Investigaciones Económicas y Sociales del Sur-UNS/CONICET y Facultad de Ciencias Económicas-UNAM (iD ORCID: https://orcid.org/0000-0002-8347-9808 | Correo electrónico: fernando_gonzalez01@hotmail.com 


\section{Abstract}

Natural disasters pose a serious threat globally and, in the future, their frequency and severity are expected to increase due to climate change. Empirical evidence has reported conflicting results in terms of the impact of disasters on economic growth. In this context, the aim of this paper is to synthesize the recent empirical evidence in this topic. For this, meta-analysis and meta-regression techniques are employed. More than 650 estimates, from studies published in the last five years (2015-2020), are used. The review includes three sources (Scopus, Science Direct, and Google Scholar). The results identified the existence of a negative and significant combined effect (-0.015). Developing countries are especially vulnerable to disasters. The negative impact is greater for disasters that occurred in the last decade -in relation to previous disasters-. These findings constitute a call for attention in favour of mitigation and adaptation policies.

Keywords: disasters, growth, GDP, meta-analysis, meta-regression

\section{Resumen}

Los desastres naturales representan una grave amenaza a nivel mundial y, a futuro, se espera que su frecuencia y severidad aumenten debido al cambio climático. La evidencia empírica ha reportado resultados contradictorios en términos del impacto de los desastres en el crecimiento económico. En este contexto, el objetivo de este trabajo es sintetizar la evidencia empírica reciente de este tópico. Para ello se emplean técnicas de meta-análisis y meta-regresión. Se incluyen más de 650 estimaciones, de estudios publicados en los últimos cinco años (2015-2020). La revisión incluye tres fuentes (Scopus, Science Direct y Google Scholar). Los resultados identificaron la existencia de un efecto combinado negativo y significativo (-0.015). Los países en desarrollo son especialmente vulnerables frente a desastres. El impacto negativo es mayor para los desastres ocurridos en la última década -en relación a desastres anteriores-. Estos hallazgos constituyen un llamado de atención a favor de políticas de mitigación y adaptación.

Palabras clave: desastres, crecimiento, PIB, meta-análisis, meta-regresión 


\section{Introduction}

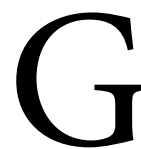
lobally, an increasing amount of natural disasters takes place every year. This includes climatological, meteorological, hydrological and geophysical disasters (Center for Research on the Epidemiology of Disasters [CRED], 2020). In 2018 alone, natural disasters caused losses of US\$ 132 billion and affected more than 68 million people globally (CRED, 2019). Its frequency and severity are expected to increase, in the future, as a consequence of climate change (Intergovernmental Panel on Climate Change [IPCC], 2018).

Undoubtedly, the occurrence of a disaster reduces the well-being of those affected (Rabassa et al., 2014; González, 2020). From the impact on their health, damage to infrastructure, and even destruction of the natural environment, the effect appears to be unambiguous. However, its impact on economic activity -and in particular on output growth- does not seem so evident. Thus, three theoretical hypotheses have been postulated regarding the impact of natural disasters on economic growth (Hsiang and Jina, 2014).

In the first place, a recovery to the trend is conceivable. This is, after the disaster, a lower GDP growth is observed, associated with the destruction of physical and human capital. However, given the relative capital shortage in the affected region, a capital inflow occurs and temporarily raises growth above pre-disaster levels. Eventually the inflow of capital stops and growth returns to that corresponding to the steady state of the economy. This is the standard prediction of neo-classical growth models. The empirical evidence seems to support the prediction of a wealth flow, although no migratory flows to the affected areas are observed.

Second, the non-recovery hypothesis holds that the economy does not return to its previous steady state. That is, the capital flow is tempered by other effects. A broad drop in consumption can raise its marginal utility so that it is preferable to productive investments. Although the growth rate returns to its pre-disaster levels, output will be sustained lower.

Third, the build back better hypothesis predicts that after a brief period of slower growth due to loss of capital, this is replaced by new capital more productive than the destroyed. This results in an increase in the GDP growth rate and in a new (and better) steady state. Here it is assumed that, in the absence of disaster, companies do not efficiently update their capital stock. This may be due to restrictions on access to credit and which would be relaxed post-disaster. In a related way, the creative destruction hypothesis maintains that, even in the short term, greater economic growth can be observed given the greater demand for reconstruction goods and services. This seems to be especially true for sectors such as construction.

Empirical evidence has reported mixed results. On the one hand, a large group of works suggests a negative and significant effect, derived from the occurrence of a natural disaster, on growth -in the short term- (Noy, 2009; Strobl, 2011; Berlemann and Wenzel, 2016; IMF, 2018; González et al., 2021a). Other studies, however, report a positive effect on growth (Albala-Bertrand, 1993; Skidmore and Toya, 2002; Porcelli and Trezzi, 2018). The absence of significant effects has been reported in Cavallo et al. (2013) 
who point out that only those catastrophic disasters -above the 99th percentile of the global distribution of mortality from disasters- that lead to a situation of institutional instability reduce economic growth.

In this context, the objective of this work is to synthesize the empirical evidence regarding the impact that the occurrence of natural disasters has on economic growth. For this, this work implements meta-analysis and meta-regression techniques. To the best of our knowledge, this work contributes to the disaster literature in two ways. First, it updates the available evidence on this topic by considering, in the meta-analysis, works published until March 2020 -while the existing background only includes works published until 2014-. Second, it provides evidence of temporal differences in the impact of natural disasters. That is, it distinguishes between contemporary effect and lagged effects. The findings of this work constitute a wake-up call towards the implementation of mitigation and adaptation policies against natural disasters and climate change, which must consider different levels of government and be multidimensional (Kashwan, 2018).

Meta-analysis is a technique that allows synthesizing the empirical evidence in a statistically robust way and estimating a combined effect -considering evidence from different studies- (Florax et al., 2002). In contexts of conflicting results, the meta-analysis and the meta-regression allow explaining the existing differences (i.e. different geographic or temporal scope, econometric specification or source of information). Initially used in Medicine, this systematic review technique has become frequent in Economics (Stanley, 2001) and its application includes topics such as the effectiveness of labor policies (Card et al., 2010), education and growth (Benos and Zotou, 2014), discrimination (Lane, 2016), publication bias (Andrews and Kasy, 2019) or elasticity of demand (Havranek and Sokolova, 2020).

Previously, three studies have advanced in the joint study -by means of meta-analysis techniques- of the existing empirical evidence on the impact of natural disasters on economic growth (Lazzaroni and van Bergeijk, 2013; Klomp and Valckx, 2014; van Bergeijk and Lazzaroni, 2015). Lazzaroni and van Bergeijk (2013) find mixed results when considering publications made between 2002-2013 and using a multinomial logistic model. In particular, they find that the probability of reporting a negative and significant estimate, among the studies considered, is $38 \%$ followed by non-significant estimates (36\%) and positive and significant estimates (26\%). When distinguishing between estimates that report direct effects of natural disasters (destruction of physical assets) from those that refer to their indirect effects (lower economic flows), they find that the latter have an $88 \%$ greater probability of reporting a positive and significant effect. That is, there is a greater consensus in relation to the destruction of physical assets caused by the occurrence of natural disasters than in relation to its negative impact on economic growth.

Klomp and Valckx (2014) report evidence in favour of the existence of a negative impact of natural disasters on GDP growth. This impact is increasing over time and greater among developing countries and for climate disasters. The authors also find evidence in favour of the existence of publication bias among the studies considered ${ }^{2}$. van Bergeijk and Lazzaroni (2015) proceed with a meta-analysis on the same topic and contrast their results with those that arise from a systematic review of the literature

2- That is, the reported effect is proportional to its standard deviation. Smaller studies (with a smaller sample size and, therefore, greater standard error) report larger effects in absolute value. This responds to the preference for publishing statistically significant results. 
carried out in IPCC (2012)3. They argue that the level of confidence about the existence of a negative effect caused by natural disasters is higher if the standard literature review is complemented by the meta-analysis. Their results also suggest that there is a greater consensus regarding the direct effects of disasters than in relation to their indirect effects.

Hereafter, section 1 describes the sources of information and methodology. Section 2 presents the main results, while section 3 discusses the main conclusions of the work.

\section{Methodology}

The relevant studies were selected based on a searching by keywords ("economic growth" and "natural disasters") in three well-known search engines: Scopus, Science Direct and Google Scholar. Those studies published between 2015-2020 were considered -that is, since the last meta-analysis to the authors' knowledge-. These studies include refereed journal publications and working papers. The search ended on March 20, 2020.

Those studies consisting of autoregressive vector models or input-output matrices were not considered, since the former do not present tabulated results -but impulse-response functions- and the latter do not provide standard deviations (Lazzaroni and van Bergeijk, 2013). Nor were considered studies that only report the standard deviations of the significant coefficients, those that do not report the deviations or those that do not indicate the number of observations. Studies using any proxy of the output -such as night lights- were ruled out ${ }^{4}$.

In total, 681 estimates relating natural disasters to economic growth were included, corresponding to 19 studies. These studies typically proceed with a Barro-type empirical panel strategy as the following:

$y_{i t, t-1}=\beta_{0}+\beta_{1}$ Disaster $_{i t}+\beta_{2} X_{i t}+\varepsilon_{i t}$

where $y_{i t, t-1}$ is the growth rate of the logarithm of GDP for the observational unit $i$ (frequently countries) between the years $t \mathrm{y}_{t-1}$. Disaster it is the variable of interest and that captures exposure to disasters (simple count of their frequency or some measure that includes a weight for their severity). $X_{i t}$ it is a vector of covariates that include different controls (unobserved heterogeneity, openness to international trade, human capital, quality of institutions, etc.) and $\varepsilon_{i t}$ is the model error term.

All the considered estimates refer to the effect of natural disasters on the growth rate of the GDP -in no case on the output in levels. Furthermore, $69 \%$ of the estimates refer to the contemporary effect of natural disasters, that is, the effect within the year of their occurrence. The remaining $31 \%$ consider at least one annual lag of the effect. Table 1 details the 19 studies considered.

3- In the Special Report "Managing the Risks of Extreme Events and Disasters to Advance Climate Change Adaptation" the IPCC concludes that there is a medium level of confidence regarding the existence of a negative effect of disasters on economic growth. The confidence levels contemplate qualitative categories (low, medium and high) according to the criteria of the authors of the report -considering the number of existing studies, type and consistency of the results-.

4- Excluded studies include: Doyle and Noy (2015), du Pont IV and Noy (2015), du pont IV et al. (2015), Dopke and Maschke (2016), Shaari et al. (2016, 2017), Ying and Shi (2016), Bello (2017), Cashin et al. (2017), Gerling (2017), Boccard (2018), Mohan et al. (2018), Mukherjee and Hastak (2018), Poledna et al. (2018), Zhu et al., (2018) and Tang et al. (2019). 
Table 1

Studies incorporated in the meta-analysis

\begin{tabular}{|l|l|l|l|l|l|}
\hline STUDY & $\begin{array}{l}\text { NUMBER OF } \\
\text { ESTIMATES }\end{array}$ & PERIOD & $\begin{array}{l}\text { NUMBER OF } \\
\text { COUNTRIES }\end{array}$ & $\begin{array}{l}\text { PUBLISHED } \\
\text { IN JOURNAL }\end{array}$ & $\begin{array}{l}\text { S JR IMPACT } \\
\text { FACR }\end{array}$ \\
\hline Guo et al. (2015) & 6 & $1985-2011$ & 1 & Yes & 0.58 \\
\hline Hochrainer-Stigler (2015)a & 8 & $1970-2006$ & - & Yes & -- \\
\hline $\begin{array}{l}\text { Berlemann and Wenzel } \\
\text { (2016) }\end{array}$ & 3 & $1960-2002$ & 153 & Yes & 0.20 \\
\hline López et al. (2016) & 6 & $1970-2013$ & 184 & No & -- \\
\hline Mu and Chen (2016) & 28 & $1990-2012$ & 1 & Yes & 0.81 \\
\hline Okuyama (2016) & 11 & $1975-2006$ & 1 & Yes & -- \\
\hline de Oliveira (2017) & 60 & $2002-2011$ & 1 & No & -- \\
\hline SELA-UNISDR (2017) & 5 & $1970-2014$ & 10 & No & -- \\
\hline $\begin{array}{l}\text { Bakkensen and Barrage } \\
\text { (2018) }\end{array}$ & 9 & $1970-2015$ & 182 & No & -- \\
\hline Brata et al. (2018) & 10 & 2006 & 1 & Yes & -- \\
\hline IMF (2018) & 128 & $1980-2016$ & 12 & No & -- \\
\hline Ishizawa and Miranda (2018) & 16 & $1983-2010$ & 6 & Yes & 1.40 \\
\hline Lima and Barbosa (2018) & 54 & $2008-2010$ & 1 & Yes & 0.91 \\
\hline Porcelli and Trezzi (2018) & 80 & $1986-2011$ & 1 & Yes & 0.59 \\
\hline Zhao et al. (2018) & 34 & $2003-2013$ & 1 & Yes & 0.58 \\
\hline Heger and Neumayer (2019) & 60 & $2006-2012$ & 1 & Yes & 3.58 \\
\hline Mantey et al. (2019) & 64 & $1980-2015$ & 50 & Yes & -- \\
\hline Panwar and Sen (2019) & 39 & $1981-2015$ & 29 & -- \\
\hline Parida et al. (2020) & 60 & $1981-2011$ & 1 & 0.55 \\
\hline
\end{tabular}

Source: own elaboration

aprovides estimates on a global scale without specifying the number of countries included.

bRefers to the impact factor of Scimago Journal Rank (SJR) as reported, for 2019, at https://www.scimagojr. $\mathrm{com} /$. Those journals not indexed in Scopus do not have an impact factor.

Two estimates are made in this work: the combined effect of the point estimates of all the studies (meta-analysis) and an explanatory regression of the heterogeneity present between the included studies (meta-regression). In both cases a random effects model is considered and STATA 16.1 is used for its computation.

The combined effect $\left(\widehat{\theta_{D L}}\right)$ consists of a weighted average of the distribution of effects -following the DerSimonian and Laird method of moments (DerSimonian and Laird, 1986)-. Given the random effects model, the existence of a single true effect (fixed effect) is not assumed, but each study is conceived as a random sample of the distribution of relevant effects. Equation 2 expresses the combined effect (Bradburn et al., 1999):

$\widehat{\theta_{D L}}=\frac{\sum_{i=1}^{k} w_{i} \widehat{\theta}_{l}}{\sum_{i=1}^{k} w_{i}}$ 
where $w_{i}$ is the weight received by the study $i ; \widehat{\theta}_{l}$ is the estimated individual effect in study $i$. The weight of each study arises from considering an estimate of the inverse of its variance:

$w_{i}=\frac{1}{e s\left(\widehat{\theta_{l}}\right)^{2}+\hat{T}^{2}}$

where es $\left(\widehat{\theta}_{l}\right)$ is the standard deviation of the individual effect of study $i$; $\hat{T}$ is the variability between studies.

The meta-regression incorporates, as explanatory, dummy variables that try to explain the heterogeneity observed between the different estimates. Equation 4 details the estimation strategy used:

$\beta_{j i}=\alpha_{0}+\mathrm{a}_{1} X_{j i}+\varepsilon_{i}+\mu_{j i}$

where $\beta_{j i}$ refers to the point estimate $j$ of study $i$; $X_{j i}$ is a vector of relevant regressors; $\varepsilon_{i}$ is the specific deviation of study $i$ with respect to the average of the distribution of effects; $\mu_{j i}$ is the random error term. The regressor vector considered in this work is described below in Table 2 .

Table 2

Regressors considered in meta-regression

\begin{tabular}{ll}
\hline REGRESSOR & DESCRIPTION \\
\hline Developing countries & 1 if considers developing countries (non-OECD members), 0 otherwise \\
Decade of 2010 & 1 if considers disasters that occurred in the 2010 s, 0 otherwise \\
\hline Decade of 2000 & 1 if considers disasters that occurred in the 2000 s, 0 otherwise \\
\hline Climatological & 1 if considers climatological disasters, 0 otherwise \\
\hline Hydrological & 1 if considers hydrological disasters, 0 otherwise \\
\hline Meteorological & 1 if considers meteorological disasters, 0 otherwise \\
\hline Geophysical & 1 if considers geophysical disasters, 0 otherwise \\
\hline Single disaster & 1 if considers a single disaster, 0 otherwise \\
\hline EM-DAT & 1 if uses the EM-DAT data, 0 otherwise \\
\hline Data panel & 1 if estimates a panel specification, 0 otherwise \\
\hline Dynamic model & 1 if considers the lag of the dependent variable as regressor, 0 otherwise \\
\hline Time fixed effects & 1 if considers time fixed effects, 0 otherwise \\
\hline Idiosyncratic fixed effects & 1 if considers idiosyncratic fixed effects, 0 otherwise \\
\hline Published in journal & 1 if the study is published in a journal, 0 otherwise \\
\hline Disaster severity & 1 if weights by the severity of natural disasters, 0 otherwise \\
\hline Environ. and geography. controls & 1 if considers environmental or geographic controls, 0 otherwise \\
\hline International trade controls & 1 if considers international trade controls, 0 otherwise \\
\hline Human capital controls & 1 if considers human capital controls, 0 otherwise \\
\hline Initial GDP control & 1 if considers initial GDP controls, 0 otherwise \\
\hline Financial market development controls & 1 if considers financial market development controls, 0 otherwise \\
\hline Institutional controls & 1 if considers institutional controls, 0 otherwise \\
\hline Endogeneity controls & 1 if considers endogeneity controls, 0 otherwise \\
\hline
\end{tabular}

Source: own elaboration 


\section{Results}

The estimate of the combined effect of the occurrence of natural disasters on economic growth is presented below. A significant and negative combined effect is observed (-0.015). This reflects the fact that most studies report a negative and significant individual effect (11 out of 19 studies), followed by those reporting non-significant effects (7) and a single study with a positive and significant effect. A negative combined effect implies that the occurrence of a natural disaster significantly reduces the GDP growth rate of the affected area. This is consistent with what was previously reported (Lazzaroni and van Bergeijk, 2013; Klomp and Valckx, 2014; van Bergeijk and Lazzaroni, 2015).

Table 3

Combined and study effect of natural disasters on economic growth

\begin{tabular}{|l|l|l|l|l|}
\hline STUDY & EFFECT & P-VALUE & LL 95\% & UL 95\% \\
\hline Guo et al. (2015) & 0.000 & 0.999 & -0.050 & 0.050 \\
\hline Hochrainer-Stigler (2015) & -0.001 & 0.286 & -0.004 & 0.001 \\
\hline Berlemann and Wenzel (2016) & $-0.046^{* * *}$ & 0.000 & -0.066 & -0.026 \\
\hline López et al. (2016) & $-0.168^{*}$ & 0.067 & -0.347 & 0.012 \\
\hline Mu and Chen (2016) & $-0.002^{* * *}$ & 0.000 & -0.002 & -0.001 \\
\hline Okuyama (2016) & 0.038 & 0.178 & -0.017 & 0.094 \\
\hline de Oliveira (2017) & $-0.002^{* * *}$ & 0.000 & -0.003 & -0.001 \\
\hline SELA-UNISDR (2017) & -0.001 & 0.776 & -0.007 & 0.006 \\
\hline Bakkensen and Barrage (2018) & $-0.133^{* *}$ & 0.011 & -0.235 & -0.031 \\
\hline Brata et al. (2018) & $-1.396^{* *}$ & 0.027 & -2.635 & -0.156 \\
\hline IMF (2018) & $-1.926^{* * *}$ & 0.000 & -2.106 & -1.745 \\
\hline Ishizawa and Miranda (2018) & $-0.011^{* * *}$ & 0.000 & -0.013 & -0.009 \\
\hline Lima and Barbosa (2018) & $-0.055^{* * *}$ & 0.000 & -0.067 & -0.044 \\
\hline Porcelli and Trezzi (2018) & $0.058^{* *}$ & 0.033 & 0.005 & 0.111 \\
\hline Zhao et al. (2018) & $-0.541^{* * *}$ & 0.000 & -0.668 & -0.414 \\
\hline Heger and Neumayer (2019) & 0.002 & 0.669 & -0.006 & 0.010 \\
\hline Mantey et al. (2019) & $-0.247^{* * *}$ & 0.000 & -0.276 & -0.218 \\
\hline Panwar and Sen (2019) & -0.001 & 0.417 & -0.003 & 0.001 \\
\hline Parida et al. (2020) & -0.000 & 0.625 & -0.002 & 0.001 \\
\hline Combined effect & $-0.015^{* * *}$ & 0.000 & $-0-018$ & -0.012 \\
\hline & & - & \\
\hline
\end{tabular}

Source: own elaboration

Note: ${ }^{*}$ significant at $10 \%,{ }^{* *}$ significant at $5 \%,{ }^{* * *}$ significant at $1 \%$. A forest diagram with each point estimate $(\mathrm{N}=681)$ is omitted for simplicity.

Table 3 also shows a wide heterogeneity between the individual estimates of different studies. Thus, an average individual effect (negative and significant) of -1.9 is reported in IMF (2018), while an individual effect (positive and significant) of 0.058 arises from Porcelli and Trezzi (2018). Furthermore, the presence of heterogeneity in the estimated effect can be observed when considering different groups of point estimates (Graph 1). 
Graph 1

Forest plot of total combined effect and by subgroups

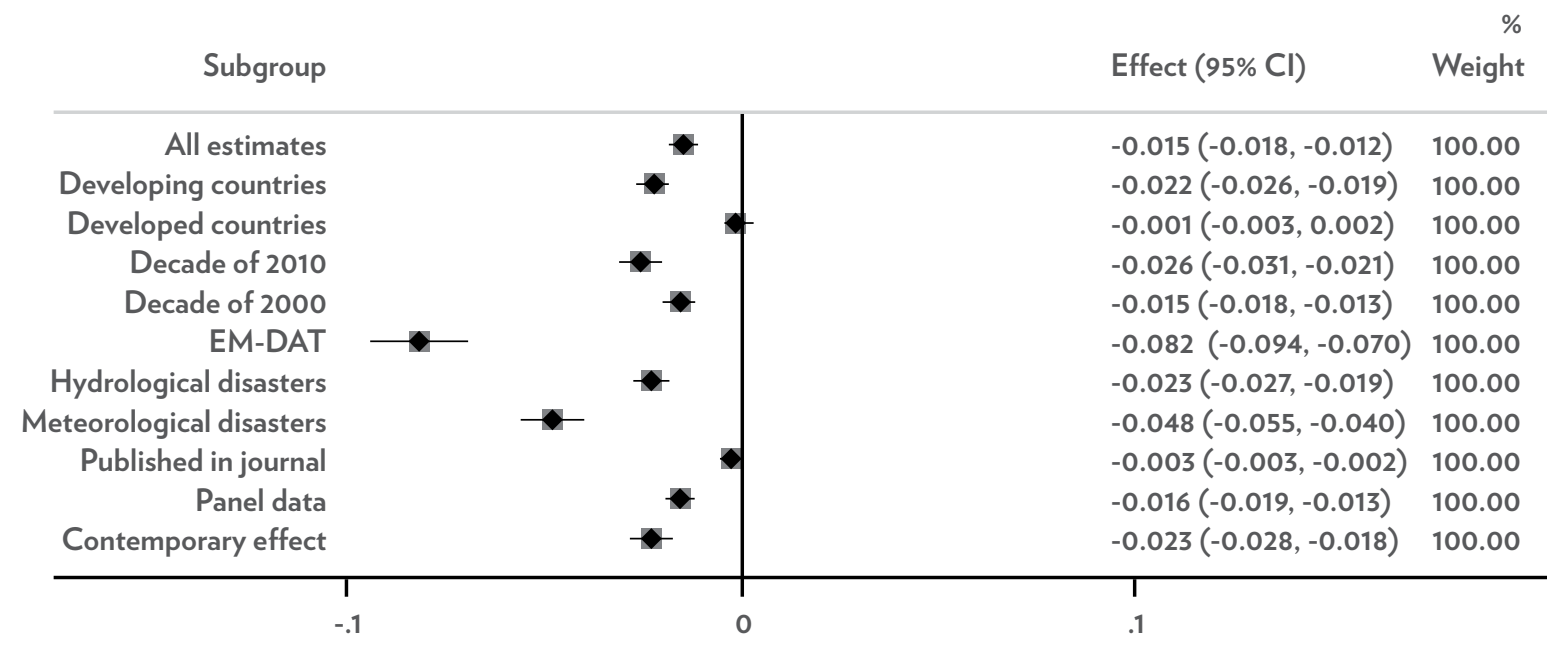

Source: own elaboration

Note: each row refers to the combined effect for the specified subgroup. The first row considers all the point estimates and is the same one that appears in Table 3.

From Graph 1 it appears that the negative effect of disasters seems greater in developing countries than in developed ones. In turn, those estimates made considering EM-DAT or meteorological disasters as a source of information tend to report a greater negative effect. Another way to contemplate this wide dispersion, which allows visualizing the point estimates in a disaggregated form, is through funnel plots.

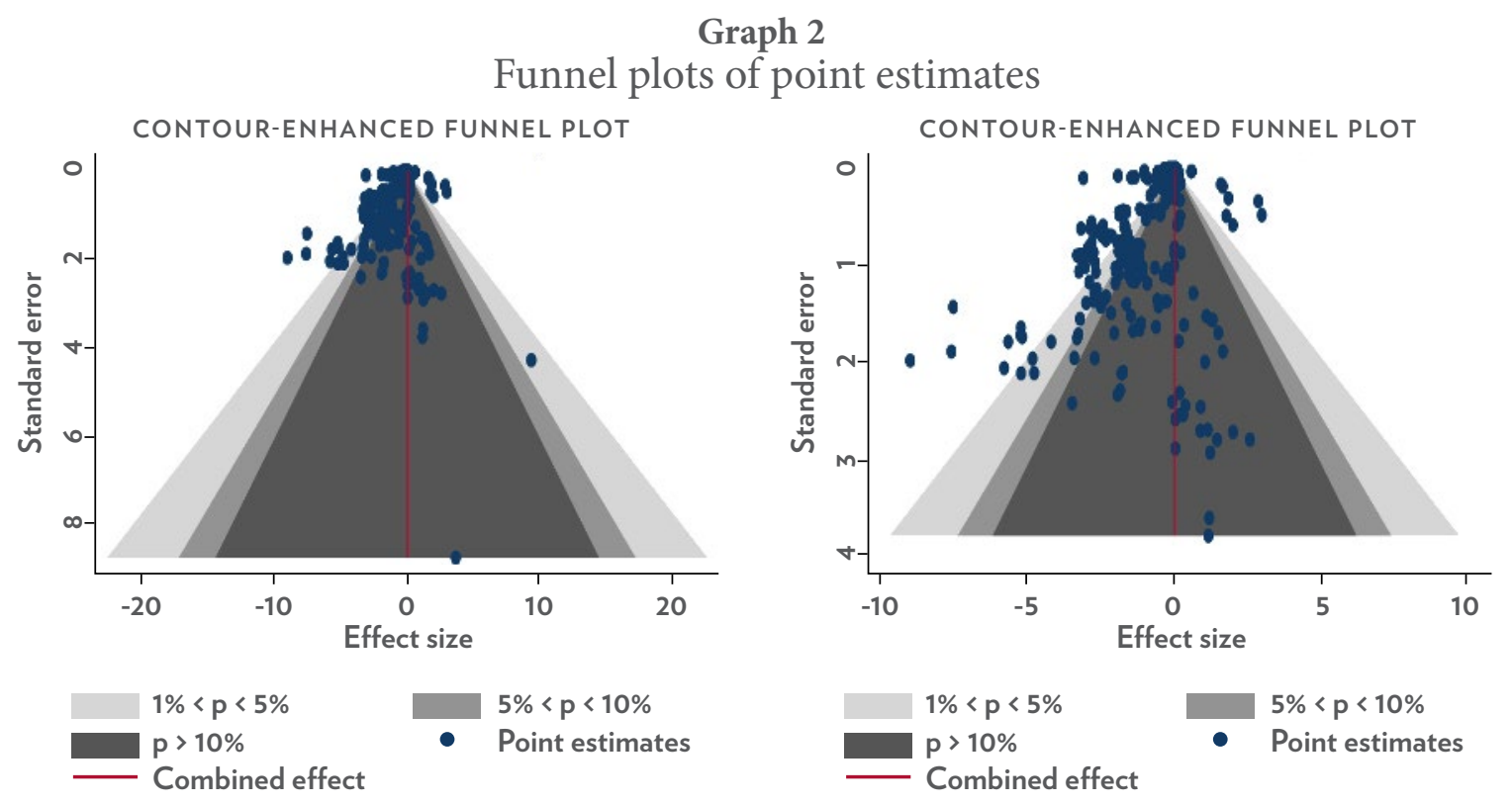

Source: own elaboration

Note: The diagram on the left considers the 681 point estimates. The diagram on the right excludes the 2 estimates whose standard deviations are greater than 4 . The combined effect is the same as that shown in Table $3(-0.015)$. 
These plots present the estimated effect and its standard error, for each point estimate, so that the most accurate estimates appear at the top of the plot -the least accurate appear at the bottom. According to the graph, most of the point estimates are negative ( 490 of 681). Furthermore, of the significant estimates, $83 \%$ is negative. Again, a wide dispersion arises when comparing the extremes of these point estimates: -9.006 (Mantey et al., 2019) and 9.33 (Brata et al., 2018). Graphically, the above implies a higher concentration of points in the left half of each diagram. In addition, a wide dispersion of the points is observed between the significance intervals $(10 \%, 5 \%$ and $1 \%)$ and effect sizes. This is contrary to the idea of publication bias, although this study includes both journal-published studies and working papers.

Logically, it is interesting to delve into the explanation of the observed heterogeneity. Table 4 below presents the results of the meta-regression.

Table 4

Meta-regression effect of natural disasters on economic growth

\begin{tabular}{|l|l|l|}
\hline & COEFFICIENT & STANDARD ERROR \\
\hline Developing countries & $-0.499^{* * *}$ & 0.064 \\
\hline Decade of 2010 & $-1.119^{* * *}$ & 0.315 \\
\hline Decade of 2000 & $0.570^{* * *}$ & 0.103 \\
\hline Climatological & $-0.203^{* * *}$ & 0.052 \\
\hline Hydrological & -0.061 & 0.045 \\
\hline Meteorological & $0.123^{* *}$ & 0.057 \\
\hline Geophysical & -0.068 & 0.043 \\
\hline Single disaster & -0.010 & 0.087 \\
\hline EM-DAT & $-0.251^{* *}$ & 0.111 \\
\hline Data panel & -0.033 & 0.096 \\
\hline Dynamic model & -0.028 & 0.047 \\
\hline Time fixed effects & $-1.000^{* * *}$ & 0.110 \\
\hline Idiosyncratic fixed efeccts & $0.664^{* * *}$ & 0.086 \\
\hline Published in journal & $0.346^{* * *}$ & 0.121 \\
\hline Disaster severity & $0.186^{* * *}$ & 0.046 \\
\hline Environ. and geography. controls & 0.079 & 0.086 \\
\hline International trade controls & $0.247^{* *}$ & 0.124 \\
\hline Human capital controls & -0.110 & 0.122 \\
\hline Initial GDP controls & 0.127 & 0.109 \\
\hline Financial market development controls & $-0.220^{*}$ & 0.127 \\
\hline Institutional controls & -0.152 & 0.135 \\
\hline Endogeneity controls & $0.092^{*}$ & 0.057 \\
\hline N & 681 & \\
\hline R2 & $14.53 \%$ & \\
\hline I2 & $98.32 \%$ & \\
\hline & & \\
\hline & & \\
\hline
\end{tabular}

Source: own elaboration

Note: ${ }^{\star}$ significant at $10 \%,{ }^{* *}$ significant at $5 \%,{ }^{* *}$ significant at $1 \%$. I2 is a measure of the heterogeneity between studies (proportion of the variability attributable to true heterogeneity) and is constructed from the Cochran Q statistic. See Harris et al. (2008). 
Table 4 confirms what was observed in the previous graphic analysis. The negative impact of natural disasters on economic growth is greater in developing countries than in its developed peers. Also, the negative impact is greater for disasters that occurred in the last decade. This is consistent with previous literature that suggests that the impact of disasters -and in general of the consequences of climate change- is greater in more vulnerable economies and that the frequency and intensity of these have increased in recent years, on a global scale (Klomp and Valckx, 2014). The previous results would imply that climate change and disaster mitigation and adaptation policies can contribute to fighting global poverty given that developing countries concentrate a large part of the global poor (Fleming et al., 2007).

In methodological terms, some striking aspects are highlighted. The use of EM-DAT as a source of disaster information has a significantly greater negative impact. This is expected considering the requirements for a disaster to be registered in this database ${ }^{5}$. Controlling for unobserved heterogeneity -idiosyncratic or temporal- (fixed effects) also results in significant differences. Both controls for unobserved heterogeneity are the regressors with the highest absolute value as shown in Table 4, suggesting that their inclusion is relatively more important than other regressors to explain the heterogeneity between studies. In the same sense, considering some measure of disaster severity -instead of using their frequency or an occurrence dummy- yields significant differences. These results are robust to the presence of outliers (Table A.2 in Appendix).

A significant part of the heterogeneity between the analyzed studies is explained by the inclusion of international trade, development of financial markets and endogeneity controls. In any case, a large proportion of the heterogeneity between studies cannot be explained by the regressors considered here $\left(\mathrm{R}^{2}<15 \%\right)$. In order to strengthen the estimates, Table A.1 (in the Appendix) reiterates the estimates presented in Table 4, incorporating dummies to control for lagged effects (first and second lags). The results provide positive point estimates for both lags -the lagged negative effect of natural disasters would be lower than their contemporary effect. It is highlighted that only $31 \%$ of the point estimates refer to lagged effects. In this regard, Klomp and Valckx (2014) point out that less than $10 \%$ of the estimates included in their review refer to a period of more than 5 years.

When considering only those studies that report a negative and significant effect, the explanatory power of the model increases considerably ( $\left.\mathrm{R}^{2}>49 \%\right)$. However, some of the estimated coefficients do not maintain their significance.

Table 5

Meta-regression with studies reporting a significant and negative effect

\begin{tabular}{|l|l|l|}
\hline & COEFFICIENT & STANDARD ERROR \\
\hline Developing countries & $-0.756^{* * *}$ & 0.226 \\
\hline Decade of 2010 & -0.372 & 0.424 \\
\hline Decade of 2000 & 0.445 & 0.304 \\
\hline Climatological & 0.136 & 0.163 \\
\hline Hydrological & 0.121 & 0.171 \\
\hline Meteorological & $1.126^{* * *}$ & 0.214 \\
\hline
\end{tabular}

5- To be included in this database, a disaster must meet at least one of the following conditions: have generated not less than 10 deaths, at least 100 people affected, a declaration of a state of emergency or, request for international aid (CRED, 2020). 


\begin{tabular}{|c|c|c|}
\hline & COEFFICIENT & STANDARD ERROR \\
\hline Geophysical & $-1.247^{* * *}$ & 0.292 \\
\hline Single disaster & 0.160 & 0.215 \\
\hline EM-DAT & 0.126 & 0.297 \\
\hline Panel data & 0.424 & 0.300 \\
\hline Dynamic model & -0.172 & 0.248 \\
\hline Time fixed effects & $-1.608^{\star * *}$ & 0.221 \\
\hline Idiosyncratic fixed effects & 0.074 & 0.220 \\
\hline Published in journal & $1.379^{* \star *}$ & 0.268 \\
\hline Disaster severity & 0.044 & 0.061 \\
\hline Environ. and geography. controls & -0.157 & 0.175 \\
\hline International trade controls & -0.154 & 0.206 \\
\hline Human capital controls & -0.118 & 0.223 \\
\hline Initial GDP controls & -0.017 & 0.212 \\
\hline Financial market development controls & 0.317 & 0.210 \\
\hline Institutional controls & -0.265 & 0.314 \\
\hline Endogeneity controls & 0.327 & 0.308 \\
\hline N & 412 & \\
\hline $\mathrm{R}^{2}$ & $49.42 \%$ & \\
\hline 12 & $98.92 \%$ & \\
\hline
\end{tabular}

Source: own elaboration

Note: ${ }^{\star}$ significant at $10 \%,{ }^{* *}$ significant at $5 \%,{ }^{* *}$ significant at $1 \%$

In this case, the greatest negative effect for developing countries is accentuated. The lowest effects for meteorological disasters and estimates from published studies are also maintained -this is contrary to the idea of publication bias. Geophysical disasters, meanwhile, now appear with a greater negative effect than other types of disasters.

\section{Conclusions}

In a context where empirical estimates are characterized by reporting conflicting results, this work attempted to synthesize recent empirical evidence regarding the impact that the occurrence of natural disasters has on economic growth. For this, 681 point estimates from 19 studies published between 2015-2020 were considered.

The results of the meta-analysis confirm the existence of a significant and negative combined effect. That is, the occurrence of a natural disaster significantly reduces the economic growth of the affected economy. Thus, this work contributes to increasing confidence in the existence and direction of this effect.

When exploring the sources of heterogeneity between studies, it was observed that developing countries are particularly exposed to the negative effects of the occurrence of disasters. The effects of the disasters that occurred in the last decade are presented as more negative than those corresponding to previous decades. Some methodological decisions in the estimation strategies used also generate significant differences: the use of the EM-DAT records, the inclusion of fixed effects -by observational or tem- 
poral units-, the weighting by severity of disasters and the control by aspects such as international trade, development of financial markets and endogeneity. Some of these aspects, however, are not robust when considering only the subgroup of studies whose individual effect is negative and significant.

The results reported here show positive point estimates -although not significant- for the lagged effects of the occurrence of natural disasters on growth. Exploring the effect of disasters beyond the short term (more than a year after their occurrence) is especially complex considering that only $31 \%$ of all point estimates refer to lagged effects. Thus, although there is a negative effect in the short term, more evidence is necessary to achieve robust estimates regarding persistence in the medium and long term. In the future, it is desirable to also have intra-annual estimates that allow identifying the impact of disasters in periods of less than a year.

Considering that in the future an increase in the frequency and severity of the occurrence of natural disasters is expected, the results of this work constitute a clear call for attention towards an active implementation of public policies for mitigation and adaptation. This is especially true for developing countries where the evidence agrees to highlight that the negative effects of natural disasters are greater, including long-lasting effects on human development and a higher mortality risk (González et al., 2020 ; 2021b). Thus, the implementation of these policies not only contributes to reducing vulnerability to disasters, but also constitutes true tools to combat poverty on a global scale.

\section{References}

Albala-Bertrand, J. (1993). Natural disaster situations and growth: A macroeconomic model for sudden disaster impacts. World Development, 21(9): 1417-1434. https://doi.org/10.1016/0305750X(93)90122-P

Andrews, I., y Kasy, M. (2019). Identification of and Correction for Publication Bias. American Economic Review, 109(8): 2766-2794. https://doi.org/10.1257/aer.20180310

Bakkensen, L., y Barrage, L. (2018). Climate shocks, cyclones, and economic growth: Bridging the micro-macro gap. Working paper 24893, NBER. https://www.nber.org/papers/w24893

Bello, O. (2017). Disasters, economic growth and fiscal response in the countries of Latin America and the Caribbean, 1972-2010. CEPAL Review, 121: 1-23. https://repositorio.cepal.org/bitstream/ handle/11362/42007/1/RVI121_Bello.pdf

Benos, N., y Zotou, S. (2014). Education and Economic Growth: A Meta-Regression Analysis. World Development, 64: 669-689. https://doi.org/10.1016/j.worlddev.2014.06.034

Berlemann, M., y Wenzel, D. (2016). Long-term Growth Effects of Natural Disasters - Empirical Evidence for Droughts. Economic Bulletin, 36(1): 1-14. http://www.accessecon.com/Pubs/EB/2016/ Volume36/EB-16-V36-I1-P47.pdf

Boccard, N. (2018). Natural disasters over France a 35 years assessment. Weather and Climate Extremes, 22: 59-71. https://doi.org/10.1016/j.wace.2018.07.005

Bradburn, M., Deeks, J., y Altman, D. (1999). Metan- an alternative meta-analysis command. Stata Technical Bulletin, 8(44): 4-15. https://www.stata-press.com/journals/stbcontents/stb44.pdf 
Brata, A., Groot, H., y Zant, W. (2018). The Impact of the 2006 Yogyakarta Earthquake on Local Economic Growth. Economics of Disasters and Climate Change, 2: 203-224. https://doi.org/10.1007/ s41885-018-0026-5

Card, D., Kluve, J., y Weber, A. (2010). Active Labour Market Policy Evaluations: A Meta-Analysis. The Economic Journal, 120(548): 452-477. https://doi.org/10.1111/j.1468-0297.2010.02387.x

Cashin, P., Mohaddes, K., y Raissi, M. (2017). Fair weather or foul? The macroeconomic effects of El Niño. Journal of International Economics, 106: 37-54. https://doi.org/10.1016/j.jinteco.2017.01.010

Cavallo, E., Galiani, S., Noy, I., y Pantano, J. (2013). Catastrophic natural disasters and economic growth. The Review of Economics and Statistics, 95(5): 1549-1561.

CRED. (2019). Natural disasters in 2018. Report of Centre for Research on the Epidemiology of Disasters. https://www.cred.be/natural-disasters-2018

CRED. (2020). EM-DAT database. https://public.emdat.be/

De Olivera, H. (2017). Natural Disasters and Economic Growth in the Northeastern Brazil: Evidence from Municipal Economies of the State of Ceará. Working paper, IPECE. https://www.ipece.ce.gov. br/wp-content/uploads/sites/45/2017/11/Natural-Disasters-and-Economic-Growth-in-theNortheastern-Brazil-Evidence-from-Municipal-Economies-of-the-State-of-Cear\%C3\%A1.pdf

DerSimonian, R., y Laird, N. (1986). Meta-analysis in clinical trials. Controlled Clinical Trials, 7(3): 177-188. https://doi.org/10.1016/0197-2456(86)90046-2

Dopke, J., y Maschke, P. (2016). Alternatives to GDP - Measuring the impact of natural disasters using panel data. Journal of Economic and Social Measurement, 41(3): 265-287. https://doi. org/10.3233/JEM-160429

Doyle, L., y Noy, I. (2015). The short-run nationwide macroeconomic effects of the Canterbury earthquakes. New Zealand Economic Papers, 49(2): 134-156. https://doi.org/10.1080/007799 54.2014 .885379

du Pont IV, W., y Noy, I. (2015). What Happened to Kobe? A Reassessment of the Impact of the 1995 Earthquake in Japan. Economic Development and Cultural Change, 63(4): 777-812. https://doi. org/10.1086/681129

du Pont IV, W., Noy, I., Okuyama, Y., y Sawada, Y. (2015). The Long-Run Socio-Economic Consequences of a Large Disaster: The 1995 Earthquake in Kobe. PloS ONE, 10(10): 1-17. https://doi. org/10.1371/journal.pone.0138714

Fleming, S., Cox, M., Sen, K., y Wright-Revolledo, K. (2007). Strengthening the Poverty Impact of the Paris Declaration: Aid Effectiveness evidence gathering project on gender equality, human rights and social exclusion. https://www.oecd.org/dac/gender-development/38788905.pdf

Florax, R., de Groot, H., y de Mooij, R. (2002). Meta-analysis: A Tool for Upgrading Inputs of Macroeconomic Policy Models. Discussion paper 02-041/3, Tinbergen Institute. https://research.vu.nl/en/ publications/meta-analysis-a-tool-for-upgrading-inputs-of-macroeconomic-policy

Gerling, K. (2017). The Macro-Fiscal Aftermath of Weather-Related Disasters: Do Loss Dimensions Matter?. Working paper 17/235, IMF. https://www.imf.org/en/Publications/WP/Issues/2017/11/08/ The-Macro-Fiscal-Aftermath-of-Weather-Related-Disasters-Do-Loss-Dimensions-Matter-45296 González, F. (2020). Natural disasters and mortality: A probabilistic Analysis for Argentina. Revista de Estudios Andaluces, 40: 78-95. https://doi.org/10.12795/rea.2020.i40.05 
González, F., London, S., y Dip, J. (2021b). Long-lasting effects of pandemics: The case of the 1918 Influenza pandemic in Argentina. Spatial and Spatio-Temporal Epidemiology, 37. https://doi. org/10.1016/j.sste.2021.100409

González, F., London, S., y Santos, M. (2021a). Disasters and Economic Growth. Climate and Development. https://doi.org/10.1080/17565529.2021.1873724

González, F., Santos, M., y London, S. (2020). Persistent effects of natural disasters on human development: quasi-experimental evidence for Argentina. Environment, Development and Sustainability. https://doi.org/10.1007/s10668-020-01064-7

Guo, J., Liu, H., Wu, X., Gu, J., Song, S., y Tang, Y. (2015). Natural Disasters, Economic Growth and Sustainable Development in China-An Empirical Study Using Provincial Panel Data. Sustainability, 7(12), 16783-16800. https://doi.org/10.3390/su71215847

Harris, R., Bradburn, M., Deeks, J., Harbord, R., Altman, D., ySterne, J.(2008). metan:fixed- and random-effects meta-analysis. The Stata Journal, 8(1): 3-28. https://doi.org/10.1177/1536867X0800800102

Havranek, T., y Sokolova, A. (2020). Do consumers really follow a rule of thumb? Three thousand estimates from 144 studies say "probably not". Review of Economic Dynamics, 35: 97-122. https:// doi.org/10.1016/j.red.2019.05.004

Heger, M., y Neumayer, E. (2019). The impact of the Indian Ocean tsunami on Aceh's long-term economic growth. Journal of Development Economics, 141: 1-17. https://doi.org/10.1016/j.jdeveco.2019.06.008

Hochrainer-Stigler, S. (2015). Natural Disasters and Macroeconomic Performance: An Empirical Analysis Based on an Econometric Modelling Approach. Journal of Integrated Disaster Risk Management, 5(1): 21-41. https://doi.org/10.5595/idrim.2015.009

Hsiang, S., y Jina, A. (2014). The causal effect of environmental catastrophe on long-run economic growth: evidence from 6700 cyclones. Working paper 20352, NBER. https://www.nber.org/papers/w20352

IMF. (2018). The Economic Impact of Natural Disasters in Pacific Island Countries: Adaptation and Preparedness. Working paper 18/108, International Monetary Fund. https://www.imf.org/en/ Publications/WP/Issues/2018/05/10/The-Economic-Impact-of-Natural-Disasters-in-Pacific-Island-Countries-Adaptation-and-45826

IPCC. (2012). Managing the risks of extreme events and disasters to advance climate change adaptation. https://www.ipcc.ch/site/assets/uploads/2018/03/SREX_Full_Report-1.pdf

IPCC. (2018). Impacts of $1.5^{\circ} \mathrm{C}$ Global Warming on Natural and Human Systems, en: Global Warming of $1.5^{\circ} \mathrm{C}$. An IPCC Special Report on the impacts of global warming of $1.5^{\circ} \mathrm{C}$ above pre-industrial levels and related global greenhouse gas emission pathways, in the context of strengthening the global response to the threat of climate change, sustainable development, and efforts to eradicate poverty. https://www.ipcc.ch/sr15/

Ishizawa, O., y Miranda, J. (2018). Weathering Storms: Understanding the Impact of Natural Disasters in Central America. Environmental and Resource Economics, 73: 181-211. https://doi. org/10.1007/s10640-018-0256-6

Kashwan, P. (2018). Economic justice in the age of climate change. Policy Brief 5, Council for the Development of Social Science Research in Africa. https://codesria.org/IMG/pdf/-224.pdf

Klomp, J., y Valckx, K. (2014). Natural disasters and economic growth: A meta-analysis. Global Environmental Change, 26: 183-195. https://doi.org/10.1016/j.gloenvcha.2014.02.006 
Lane, T. (2016). Discrimination in the laboratory: A meta-analysis of economics experiments. European Economic Review, 90: 375-402. https://doi.org/10.1016/j.euroecorev.2015.11.011

Lazzaroni, S., y van Bergeijk, P. (2013). Natural disasters impact, factors of resilience and development: A meta-analysis of the macroeconomic literature. Working paper 554, ISS. https://repub.eur.nl/pub/39446/

Lima, R., y Barbosa, A. (2018). Natural disasters, economic growth and spatial spillovers: Evidence from a flash flood in Brazil. Papers in Regional Science, 98(2): 905-925. https://doi.org/10.1111/pirs.12380

Lopez, R., Thomas, V., y Troncoso, P. (2016). Economic growth, natural disasters and climate change: New empirical estimates. Working paper SDT 434, Facultad de Economía y Negocios Universidad de Chile. http://repositorio.uchile.cl/handle/2250/143427

Mantey, K., y Poku, F. (2019). Natural disasters and economic growth in Africa. Working paper 95588, MIRA. https://mpra.ub.uni-muenchen.de/95588/4/MPRA_paper_95588.pdf

Mohan, P., Outtara, B., y Strobl, E. (2018). Decomposing the Macroeconomic Effects of Natural Disasters: A National Income Accounting Perspective. Ecological Economics, 146: 1-9. https://doi. org/10.1016/j.ecolecon.2017.09.011

$\mathrm{Mu}, \mathrm{J} ., \mathrm{y}$ Chen, Y. (2016). Impacts of large natural disasters on regional income. Natural Hazards, 83: 1485-1503. https://doi.org/10.1007/s11069-016-2372-3

Mukherjee, S., y Hastak, M. (2018). Novel Methodological Approach to Estimate the Impact of Natural Hazard-Induced Disasters on Country/Region-Level Economic Growth. International Journal of Disaster Risk Science, 9: 74-85. https://doi.org/10.1007/s13753-017-0156-3

Noy, I. (2009). The macroeconomic consequences of disasters. Journal of Development Economics, 88(2): 221-231. https://doi.org/10.1016/j.jdeveco.2008.02.005

Okuyama, Y. (2016). Long-run effect of a disaster: case study on the Kobe earthquake. The Singapore Economic Review, 61(1): 1-18. https://doi.org/10.1142/S0217590816400099

Panwar, V., y Sen, S. (2019). Economic Impact of Natural Disasters: An Empirical Re-examination. Margin. The Journal of Applied Economic Research 13(1): 109-139. https:/doi. org/10.1177/0973801018800087

Parida, Y., Saini, S., y Chowdhury, J. (2020). Economic growth in the aftermath of floods in Indian states. Environment, Development and Sustainability, 23: 535-561. https://doi.org/10.1007/ s10668-020-00595-3

Poledna, S., Hochrainer-Stigler, S., Miess, M., Klimek, P., Schmelzer, S., Sorger, J., Shchekinova, E., Rovenskaya, E., Linnerooth-Bayer, J., Dieckmann, U., y Thurner, S. (2018). When does a disaster become a systemic event? Estimating indirect economic losses from natural disasters. Working Paper, Cornell University. https://arxiv.org/abs/1801.09740

Porcelli, F., y Trezzi, R. (2018). The impact of earthquakes on economic activity: evidence from Italy. Empirical Economics, 56, 1167-1206. https://doi.org/10.1007/s00181-017-1384-5

Rabassa, M., Skoufas, E., Jacoby, H. (2014). Weather and Child Health in Rural Nigeria. Policy Research Working Paper 6214. https:/openknowledge.worldbank.org/bitstream/handle/10986/12051/ wps6214.pdf\%3Bjsessionid\%3D77B1C9F6995D0744E5089089394BE892?sequence\%3D1

SELA-UNISDR. (2017). Impacto Macroeconómico de los Desastres por la Ocurrencia de Eventos Naturales en América Latina y el Caribe. Working paper SP/RRIMDOENALC/DT No /DT N 1-17. http://www.sela.org/media/3205115/impacto-macroeconomico-desastres-ocurrencia-eventos-naturales.pdf 
Shaari, M., Karim, M., y Basri, B. (2016). Flood disaster and GDP growth in Malaysia. European Journal of Business and Social Sciences, 4(10): 27-40. http://repo.uum.edu.my/18240/1/EJBSS\%20 4\%2010\%202016\%2027-40.pdf

Shaari, M., Karim, M., y Basri, B. (2017). Does Flood Disaster Lessen GDP Growth? Evidence from Malaysia’s Manufacturing and Agricultural Sectors. Malaysian Journal of Economic Studies, 54(1): 61-81. https://smartlib.umri.ac.id/assets/uploads/files/049bc-2609-865-7820-1-10-20170530.pdf

Skidmore, M. y Toya, H. (2002). Do natural disasters promote long-run growth?. Economic Inquiry, 40(4): 664-687. https://doi.org/10.1093/ei/40.4.664

Stanley, T. (2001). Wheat From Chaff: Meta-Analysis As Quantitative Literature Review. Journal of Economic Perspectives, 15(3): 131-150. https://doi.org/10.1257/jep.15.3.131

Strobl, E. (2011). The economic growth impact of hurricanes: Evidence from U.S. coastal counties. Review of Economic and Statistics, 93(2): 575-589. https://www.mitpressjournals.org/doi/ pdf/10.1162/REST_a_00082

Tang, R., Wu, J., Ye, M., y Liu, W. (2019). Impact of Economic Development Levels and Disaster Types on the Short-Term Macroeconomic Consequences of Natural Hazard-Induced Disasters in China. International Journal of Disaster Risk Science, 10: 371-385. https://doi.org/10.1007/ s13753-019-00234-0

van Bergeijk, P., y Lazzaroni, S. (2015). Macroeconomics of Natural Disasters: Strengths and Weaknesses of Meta-Analysis Versus Review of Literature. Risk Analysis, 35(6): 1050-1072. https:// doi.org/10.1111/risa.12372

Ying, Z., y Shi, P. (2016). The Impact of Meteorological Disasters on the Economic Growth of China. Annals of International Disaster and Risk Conferences, Davos, 655-658. https://idrc.info/fileadmin/ user_upload/idrc/proceedings2016/Extended\%20Abstracts\%20IDRC\%202016_final2408.pdf

Zhao, R., Zhong, S., y He, A. (2018). Disaster Impact, National Aid, and Economic Growth: Evidence from the 2008 Wenchuan Earthquake. Sustainability, 10(12): 1-22. https://doi.org/10.3390/su10124409

Zhu, Y., Wang, Y., Liu, T., y Sui, Q. (2018). Assessing macroeconomic recovery after a natural hazard based on ARIMA - a case study of the 2008 Wenchuan earthquake in China. Natural Hazards, 91: 1025-1038. https://doi.org/10.1007/s11069-017-3163-1

\section{Appendix}

Table A.1

Meta-regression effect of natural disasters on economic growth with lagged effects

\begin{tabular}{|l|l|l|}
\hline & COEFFICIENT & STANDARD ERROR \\
\hline Developing countries & $-0.499^{* * *}$ & 0.064 \\
\hline Decade of 2010 & $-1.108^{* * *}$ & 0.315 \\
\hline Decade of 2000 & $0.567^{* * *}$ & 0.104 \\
\hline Climatological & $-0.204^{* * *}$ & 0.052 \\
\hline Hydrological & -0.063 & 0.045 \\
\hline Meteorological & $0.125^{* *}$ & 0.058 \\
\hline
\end{tabular}

(continúa...) 


\begin{tabular}{|l|l|l|}
\hline & COEFFICIENT & STANDARD ERROR \\
\hline Geophysical & -0.069 & 0.043 \\
\hline Single disaster & -0.015 & 0.088 \\
\hline EM-DAT & $-0.255^{* *}$ & 0.111 \\
\hline Panel data & -0.034 & 0.096 \\
\hline Dynamic model & -0.031 & 0.048 \\
\hline Time fixed effects & $-0.998^{* * *}$ & 0.111 \\
\hline Idiosincratic fixed effects & $0.663^{* * *}$ & 0.086 \\
\hline Published in journal & $0.345^{* * *}$ & 0.121 \\
\hline Disaster severity & $0.183^{* * *}$ & 0.047 \\
\hline Environ. and geography. controls & 0.075 & 0.087 \\
\hline International trade controls & $0.249^{* *}$ & 0.124 \\
\hline Human capital controls & -0.105 & 0.123 \\
\hline Initial GDP controls & 0.131 & 0.110 \\
\hline Financial market development controls & $-0.221^{*}$ & 0.127 \\
\hline Institutional controls & -0.155 & 0.135 \\
\hline Endogeneity controls & $0.096^{*}$ & 0.057 \\
\hline First annual lag & 0.020 & 0.032 \\
\hline Second annual lag & 0.015 & 0.042 \\
\hline N & 681 & \\
\hline R2 & $14.03 \%$ & \\
\hline I2 & $98.30 \%$ & \\
\hline & & \\
\hline
\end{tabular}

Source: own elaboration

Note: ${ }^{\star}$ significant at $10 \%,{ }^{* *}$ significant at $5 \%,{ }^{* *}$ significant at $1 \%$

Table A.2

Meta-regression effect of natural disasters on economic growth excluding outliers

\begin{tabular}{|l|l|l|}
\hline & COEFFICIENT & STANDARD ERROR \\
\hline Developing countries & $-0.240^{* * *}$ & 0.040 \\
\hline Decade of 2010 & $-0.672^{* * *}$ & 0.281 \\
\hline Decade of 2000 & $0.446^{* * *}$ & 0.062 \\
\hline Climatological & $-0.101^{* * *}$ & 0.029 \\
\hline Hydrological & 0.004 & 0.025 \\
\hline Meteorological & -0.001 & 0.032 \\
\hline Geophysical & -0.022 & 0.024 \\
\hline Single disaster & $-0.145^{* * *}$ & 0.052 \\
\hline EM-DAT & $-0.144^{* *}$ & 0.069 \\
\hline Panel data & $-0.144^{* * *}$ & 0.056 \\
\hline Dynamic model & $0.052^{*}$ & 0.028 \\
\hline Time fixed effects & $-0.551^{* * *}$ & 0.080 \\
\hline Idiosyncratic fixed effects & $0.344^{* * *}$ & 0.065 \\
\hline Published in Journal & $0.226^{* * *}$ & 0.075 \\
\hline Disaster severity & $0.138^{* * *}$ & 0.027 \\
\hline Environ. and geography. controls & $0.120^{* * *}$ & 0.048 \\
\hline
\end{tabular}

(continúa...) 


\begin{tabular}{|l|l|l|}
\hline & COEFFICIENT & STANDARD ERROR \\
\hline International trade controls & 0.128 & 0.085 \\
\hline Human capital controls & -0.053 & 0.073 \\
\hline Initial GDP controls & $0.129^{* *}$ & 0.067 \\
\hline Financial market development controls & -0.080 & 0.079 \\
\hline Institutional control & -0.082 & 0.080 \\
\hline Endogeneity controls & $-0.137^{* * *}$ & 0.035 \\
\hline $\mathrm{N}$ & 610 & \\
\hline $\mathrm{R} 2$ & $15.82 \%$ & \\
\hline $\mathrm{I} 2$ & $98.40 \%$ & \\
\hline
\end{tabular}

Source: own elaboration

Note: ${ }^{\star}$ significant at $10 \%,{ }^{* *}$ significant at $5 \%,{ }^{* *}$ significant at $1 \%$. Those point estimates located below the 5 th percentile or above the 95 th percentile of the distribution of estimated effects are excluded. That is, those point estimates less than -2.7 or greater than 0.191 . Graph 3 confirms the possible presence of outliers at the ends of the distribution.

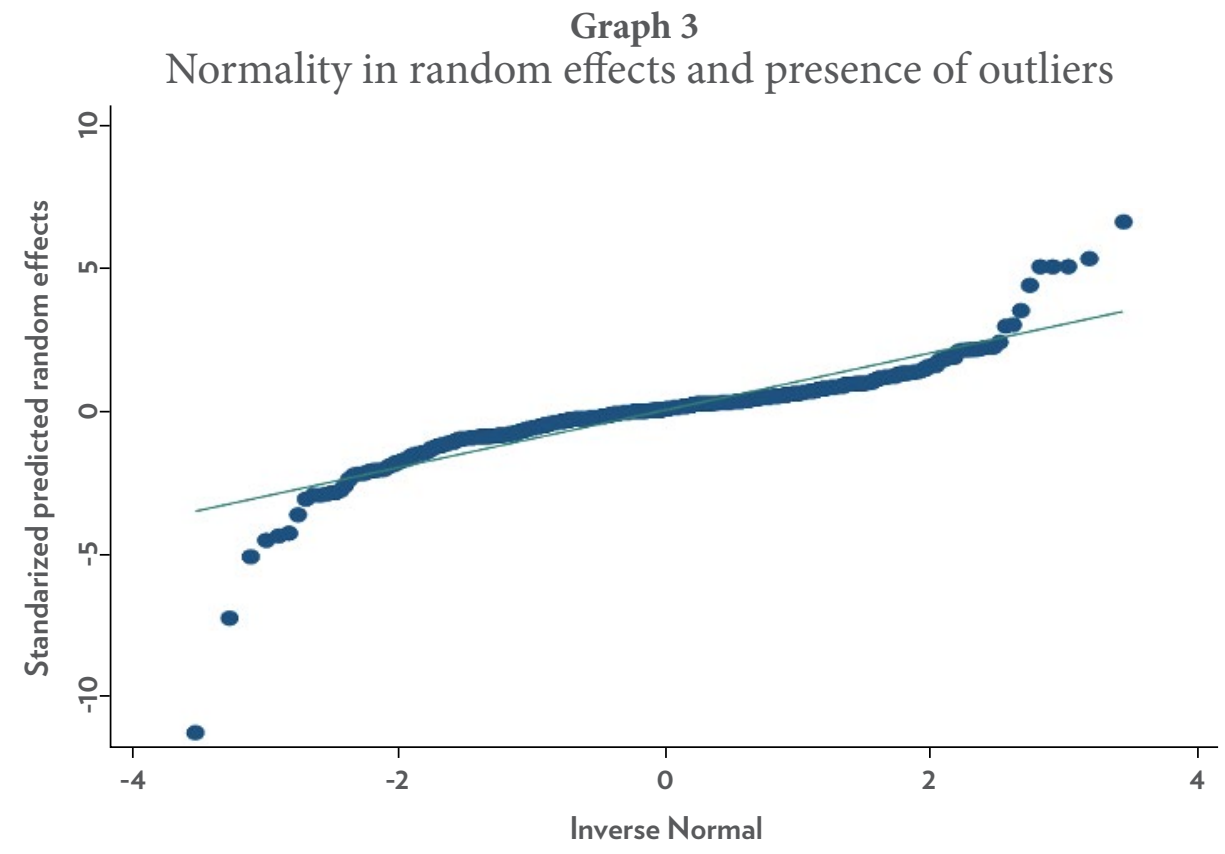

Source: own elaboration

Note: the graph shows that the effects distribution approaches a normal distribution, although the presence of outliers is observed at both ends of the distribution. Table A.2 shows that the estimates are robust to their presence. 